\title{
Long-term efficacy and safety of ramosetron in the treatment of diarrhea-predominant irritable bowel syndrome
}

This article was published in the following Dove Press journal:

Clinical and Experimental Gastroenterology

24 July 2013

Number of times this article has been viewed

\section{Toshimi Chiba \\ Kazunari Yamamoto \\ Shoko Sato \\ Kazuyuki Suzuki}

Division of Gastroenterology and Hepatology, Department of Internal Medicine, School of Medicine, Iwate Medical University, Morioka, Iwate, Japan
Correspondence: Toshimi Chiba Division of Gastroenterology and Hepatology, Department of Internal Medicine, School of Medicine, Iwate Medical University, 19-I Uchimaru Morioka, Iwate 020-8505, Japan $\mathrm{Tel}+8|1965| 51||$

Fax +81196526664

Email toschiba@iwate-med.ac.jp
Abstract: Irritable bowel syndrome (IBS) is a functional disease with persisting gastrointestinal symptoms that has been classified into four subtypes. Serotonin (5-hydroxytryptamine [5-HT]) plays important physiological roles in the contraction and relaxation of smooth muscle. Intraluminal distension of the intestine is known to stimulate the release of endogenous 5-HT from enterochromaffin cells, activating $5-\mathrm{HT}_{3}$ receptors located on primary afferent neurons and leading to increases in intestinal secretions and peristaltic activity. Ramosetron, a potent and selective 5- $\mathrm{HT}_{3}$-receptor antagonist, has been in development for use in patients suffering from diarrhea-predominant IBS. In a double-blind, placebo-controlled, parallel-group study of 418 patients with diarrhea-predominant IBS-D, once-daily $5 \mu \mathrm{g}$ and $10 \mu \mathrm{g}$ doses of ramosetron increased the monthly responder rates of IBS symptoms compared to placebo. In a 12-week randomized controlled trial of 539 patients, a positive response to treatment was reported by $47 \%$ of a once-daily $5 \mu \mathrm{g}$ dose of ramosetron-treated individuals compared to $27 \%$ of patients receiving placebo $(P<0.001)$. Furthermore, the responder rate was increased in the oral administration of $5 \mu \mathrm{g}$ of ramosetron for at least 28 weeks (up to 52 weeks), and long-term efficacy for overall improvement of IBS symptoms was also demonstrated. The rate was further increased subsequently. Adverse events were reported by $7 \%$ in ramosetron treatment. No serious adverse events, eg, severe constipation or ischemic colitis, were reported for long-term treatment with ramosetron. In conclusion, further studies to evaluate the long-term efficacy and safety of ramosetron are warranted in the form of randomized controlled trials.

Keywords: long-term efficacy, safety, ramosetron, irritable bowel syndrome

\section{Introduction}

Irritable bowel syndrome (IBS) is a functional disease with persisting gastrointestinal symptoms, mainly abdominal pain/discomfort and abnormal defecation, not accompanied by an organic disease. ${ }^{1}$ The cause of IBS is unknown, but a number of factors are thought to play a role, such as altered gastrointestinal motility, increased sensitivity of the gut, psychosocial factors, and neurotransmitter imbalances. ${ }^{2}$ According to the Rome III criteria, ${ }^{1}$ IBS is classified into four subtypes: diarrhea-predominant IBS (IBS-D), constipation-predominant IBS, mixed IBS, and unsubtyped IBS. Therapies for the treatment of IBS should therefore be targeted at improving symptoms that diminish quality of life. A number of new agents with a wide range of modes of action are currently in clinical development. ${ }^{3,4}$ Ramosetron, a potent and selective serotonin (5-hydroxytryptamine $[5-\mathrm{HT}])_{3}$-receptor antagonist ${ }^{5-8}$ has been used as a medication for gastrointestinal symptoms caused by antitumor agents, and it is also in development for use in patients suffering from IBS-D. In this article, we review the 
long-term efficacy and safety of ramosetron in the treatment of patients with IBS-D.

\section{Mechanism of action}

5-HT plays important physiological roles in the contraction and relaxation of smooth muscle, platelet aggregation, and neurotransmission. Receptors mediating the actions of 5-HT are classified into seven major groups, termed 5- $\mathrm{HT}_{1}$ to $5-\mathrm{HT}_{7}$, which include a total of 14 receptor subtypes. ${ }^{9}$ It is well known that colonic pain signals are transmitted to the spinal cord via primary nociceptive afferent neurons, and various neurotransmitters, eg, glutamate, substance P, neurotrophins, and 5-HT, are involved in the process. Among them, 5-HT is considered one of the most important neurotransmitters of visceral nociception. Intraluminal distension of the intestine, which causes abdominal pain, is known to stimulate the release of endogenous 5-HT from enterochromaffin cells, activating $5-\mathrm{HT}_{3}$ receptors located on primary afferent neurons. ${ }^{10}$ The activation of $5-\mathrm{HT}_{3}$ receptors stimulates the release of various neurotransmitters, such as acetylcholine, to induce the acceleration of colonic transit ${ }^{11}$ and abnormal water transport, ${ }^{12}$ which in turn leads to defecation abnormalities. Furthermore, it has been reported that selective $5-\mathrm{HT}_{3}$-receptor antagonists suppress abdominal pain induced by colonic distension, suggesting that $5-\mathrm{HT}_{3}$ receptors are involved in visceral nociceptive transmission. ${ }^{13}$

It has been reported that $5-\mathrm{HT}_{3}$ receptors are widely distributed within the neurons of the gastrointestinal tract, as well as in the spinal cord and brain, ${ }^{9}$ and activation of gastrointestinal 5- $\mathrm{HT}_{3}$ receptors results in intestinal secretion and peristaltic activity. ${ }^{14,15}$ The $5-\mathrm{HT}_{3}$ receptor is unique among the various 5-HT-receptor subtypes. It is a ligand-gated cation channel that belongs to the nicotine/ $\gamma$-aminobutyric acidreceptor superfamily, while all other 5-HT-receptor subtypes belong to the family of G-protein-coupled receptors. ${ }^{9}$ The neurotransmitter 5-HT has received much attention as one of the factors contributing to IBS pathogenesis. Furthermore, $5-\mathrm{HT}_{3}$-receptor antagonists have been reported to normalize defecation and to increase the perceptual threshold of the colon, ${ }^{16,17}$ suggesting the involvement of $5-\mathrm{HT}_{3}$ receptors in the pathogenesis of IBS.

In clinical settings, opioid-receptor agonists (eg, loperamide and trimebutine), muscarinic receptor antagonists (eg, tiquizium), and synthetic polymers (eg, polycarbophil calcium) are used widely for the treatment of IBS-D. ${ }^{18}$ In addition, several 5- $\mathrm{HT}_{3}$-receptor antagonists, including ramosetron, ${ }^{5}$ alosetron, ${ }^{19}$ and cilansetron, ${ }^{20}$ have been developed as therapeutic agents for IBS-D, and their effectiveness has now been established. These reports indicate that endogenous 5-HT and 5- $\mathrm{HT}_{3}$ receptors are involved in the pathogenesis of IBS. The inhibitory effect of 5-HT $\mathrm{H}_{3}$-receptor antagonists on stress-induced abnormal defecation in rats is attributable to their ameliorating effects on stress-enhanced colonic transit, but the effects of 5- $\mathrm{HT}_{3}$-receptor antagonists on abnormal water/electrolyte transport induced by stress are poorly understood. ${ }^{11}$

Ramosetron is a potent and selective $5-\mathrm{HT}_{3}$-receptor antagonist, acting mainly in peripheral tissues. ${ }^{5,21}$ It has already been proven effective in treating IBS-D in both animal and clinical studies. ${ }^{16,22,23}$ Ramosetron may achieve longlasting occupancy of $5-\mathrm{HT}_{3}$ receptors because it possesses a distinctive ability to maintain the active three-dimensional chemical conformation necessary for binding. ${ }^{24}$ In fact, it has been reported that ramosetron dissociates slowly from $5-\mathrm{HT}_{3}$ receptors $^{5,25}$ and shows long-lasting 5- $\mathrm{HT}_{3}$-receptor antagonism. ${ }^{8,26}$

In vehicle-treated rats, the colonic pain threshold was significantly decreased after 1 hour's restraint stress, whereas oral administration of ramosetron $(0.3$ to $3 \mu \mathrm{g} / \mathrm{kg})$ dose-dependently prevented this decrease in colonic pain threshold. Alosetron and cilansetron (3-30 $\mu \mathrm{g} / \mathrm{kg}$, orally) had similar effects, whereas loperamide (10 mg/kg, orally) had no effect on restraint stress-induced decrease in colonic pain threshold. Oral administration of ramosetron $(3 \mu \mathrm{g} / \mathrm{kg})$, alosetron $(30 \mu \mathrm{g} / \mathrm{kg})$, or cilansetron $(30 \mu \mathrm{g} / \mathrm{kg})$ to rats without restraint stress did not significantly affect the colonic pain threshold. ${ }^{12}$ Several $5-\mathrm{HT}_{3}$-receptor antagonists have been studied in IBS-D following observations that they slowed gastrointestinal transit. Initial studies with granisetron and ondansetron found decreased postprandial sigmoid motility, delay in colonic transit, and increased stool consistency in IBS-D. ${ }^{27}$

\section{Animal studies}

In experimental animal models, ramosetron exhibits properties that are consistent with the expected effects of a drug in this class: inhibition of stress-induced or exogenous corticotropin-releasing hormone-induced water secretion, inhibition of stress-induced acceleration of colonic transit, and inhibition of colonic nociception. ${ }^{12,22}$ Oral administration of ramosetron $(3,000 \mu \mathrm{g} / \mathrm{kg}$, once daily for 7 days $)$ did not affect normal defecation in dogs. ${ }^{12}$ Oral administration of ramosetron (10 $\mu \mathrm{g} / \mathrm{kg}$ to $100 \mu \mathrm{g} / \mathrm{kg})$ dose-dependently and significantly inhibited conditioned fear stress (CFS)induced defecation in mice. ${ }^{28,29}$ Alosetron, cilansetron, and loperamide also inhibited CFS-induced defecation, but 
their potency was less than that of ramosetron. ${ }^{28,29}$ In normal rats without $\mathrm{CFS}$, however, 5- $\mathrm{HT}_{3}$-receptor antagonists $(1,000 \mu \mathrm{g} / \mathrm{kg}$, orally) had no effect on proximal colonic transit. Ramosetron $(0.3 \mu \mathrm{g} / \mathrm{kg}-100 \mu \mathrm{g} / \mathrm{kg}$, orally) showed potent inhibitory effects on abnormal defecation on restraint stress- and 5-HT (3 mg/kg, intraperitoneally)-induced diarrhea in rats and mice, and corticotropin-releasing factor (30 $\mu \mathrm{g} / \mathrm{kg}$, intracerebroventricularly)-induced defecation in rats. Furthermore, ramosetron ( $3 \mu \mathrm{g} / \mathrm{kg}$ and $30 \mu \mathrm{g} / \mathrm{kg}$, orally) significantly prevented corticotropin-releasing factor-induced decrease in colonic fluid loss in rats. ${ }^{12}$

\section{Clinical studies and efficacy}

In a double-blind, placebo-controlled, parallel-group study of 418 patients with IBS-D, once-daily $5 \mu \mathrm{g}$ and $10 \mu \mathrm{g}$ doses of ramosetron increased the monthly responder rates of "patient-reported global assessment of relief of IBS symptoms" compared to placebo; the benefit was similar in men and women. ${ }^{30}$ In a second double-blind, placebocontrolled, parallel-group study of 539 patients with IBS-D, a once-daily $5 \mu \mathrm{g}$ dose of ramosetron was effective and well tolerated in the treatment of abdominal pain, discomfort, and altered bowel habits. ${ }^{23}$ In a 12 -week randomized controlled trial of 539 patients, a positive response to treatment was reported by $47 \%$ of ramosetron-treated individuals compared to $27 \%$ of patients receiving placebo $(P<0.001)$, relief of abdominal pain or discomfort was reported by $46 \%$ patients with ramosetron versus $33 \%$ with placebo $(P=0.005)$, and improved abnormal bowel habits were reported by $44 \%$ with ramosetron compared to $24 \%$ with placebo $(P<0.001),{ }^{23}$ which was similar to alosetron. ${ }^{31}$ The responder rates for global IBS symptoms, abdominal pain/discomfort, and abnormal bowel habits in the ramosetron and mebeverine groups significantly increased during the treatment period. The severity scores of abdominal pain/discomfort and urgency, stool form score, and stool frequency in both treatment arms were significantly reduced, compared with baselines. ${ }^{32}$ Furthermore, the responder rate was increased in the oral administration of $5 \mu \mathrm{g}$ of ramosetron for at least 28 weeks (up to 52 weeks), and long-term efficacy for overall improvement of IBS symptoms was also demonstrated in the postmarketing survey. The rate was further increased subsequently. ${ }^{33}$ Further studies to evaluate the long-term effects of ramosetron are needed in the form of randomized controlled trials (Table 1).

There are various factors that may contribute to sex differences in treatment response for patients with IBS, including biobehavioral responses to stress, sexual cycle, and sex differences in roles and emotions. Whether any of these factors may affect the response to $5-\mathrm{HT}_{3}$-receptor antagonists in either sex has not been elucidated. ${ }^{31}$ Ramosetron acts only on peripheral tissues, whereas alosetron also acts in the brain. Sex differences in the central pathophysiology of IBS have been reported. ${ }^{34,35}$ A significant association has been observed between female patients with IBS-D and polymorphisms in the serotonin-reuptake transporter protein, suggesting that the serotonin transporter is a potential candidate gene for IBS-D in women. ${ }^{36,37}$ However, it is not known whether differences in serotonin-reuptake transporter polymorphisms between women and men with IBS contribute to the observed differences in clinical response to $5-\mathrm{HT}_{3}$-receptor antagonists. ${ }^{23}$

Ondansetron was the first 5- $\mathrm{HT}_{3}$-receptor antagonist to show benefit in IBS-D; however, most of the clinical studies were performed with alosetron, which is three- to tenfold more potent and provides longer-lasting receptor inhibition. Trials showed improved stool consistency and urgency within the first week, which was only significant in females with IBS-D. ${ }^{38} \mathrm{~A}$ meta-analysis reported both alosetron and cilansetron showed significant benefit in providing satisfactory relief of IBS symptoms (pooled relative risk 1.60, 95\% confidence interval 1.49-1.72) and relief of abdominal pain and discomfort (pooled relative risk 1.30, 95\% confidence interval 1.22-1.39). 5- $\mathrm{HT}_{3}$-receptor antagonists increased the risk of constipation fourfold, with a number needed to harm of 4.7. Constipation accounted for a significant proportion of those discontinuing treatment. In this pooled analysis, both males and females showed benefit, and $0.2 \%$ had possible ischemic colitis. ${ }^{39}$

\section{Safety}

Adverse events that occurred frequently during treatment with ramosetron were abdominal distension, constipation, and hard stool, which are considered to be classic effects of $5-\mathrm{HT}_{3}$-receptor antagonists. The incidence of constipation with the administration of alosetron was $29 \%$, whereas the incidence with ramosetron was only $5.2 \%$. Ischemic colitis and severe constipation, which have been reported with alosetron use, were not observed in individuals treated with ramosetron. Although the pathogenesis of ischemic colitis in patients with IBS treated with alosetron is uncertain, ischemic colitis might arise secondary to constipation, due to the slow transit induced by alosetron. The incidence of constipation in the ramosetron group is considered to be lower than that in the alosetron group, and as a result ischemic colitis is unlikely to be caused by ramosetron. ${ }^{12,40}$ 
Table I Summary of clinical studies of ramosetron in the treatment of diarrhea-predominant irritable bowel syndrome (IBS)

\begin{tabular}{|c|c|c|c|c|c|}
\hline Study & Study design & $\begin{array}{l}\text { Sample } \\
\text { size }\end{array}$ & Efficacy & Statistical analysis & Adverse events \\
\hline $\begin{array}{l}\text { Matsueda } \\
\text { et } \mathrm{al}^{30}\end{array}$ & $\begin{array}{l}\text { Randomized } \\
\text { controlled trial }\end{array}$ & 418 & $\begin{array}{l}\text { I2-week IBS-symptom responders: } \\
42.57 \% \text { with } 5 \mu g \text { ramosetron, } \\
43.01 \% \text { with } 10 \mu g \text { ramosetron, } \\
26.92 \% \text { with placebo. }\end{array}$ & $\begin{array}{l}\text { The responder rates } \\
\text { in the ramosetron } 5 \text { and } \\
10 \mu \text { groups were higher } \\
\text { than placebo }(P<0.05) \text {. }\end{array}$ & $\begin{array}{l}\text { Neither ischemic colitis nor } \\
\text { severe constipation was } \\
\text { observed. }\end{array}$ \\
\hline $\begin{array}{l}\text { Matsueda } \\
\text { et } \mathrm{al}^{23}\end{array}$ & $\begin{array}{l}\text { Randomized } \\
\text { controlled trial }\end{array}$ & 539 & $\begin{array}{l}\text { I2-week IBS-symptom responders: } \\
47 \% \text { with } 5 \mu \text { ramosetron, } \\
27 \% \text { with placebo. }\end{array}$ & $\begin{array}{l}\text { The responder rates in } \\
\text { the ramosetron group } \\
\text { were higher than placebo } \\
(P<0.00 \text { I) }\end{array}$ & $\begin{array}{l}\text { Hard stool occurred in } \\
7.41 \% \text { in ramosetron group } \\
\text { compared with } 0.74 \% \text { in } \\
\text { placebo }(P<0.001) . \\
\text { No adverse events were } \\
\text { classified as severe. }\end{array}$ \\
\hline $\begin{array}{l}\text { Matsueda } \\
\text { et } \mathrm{al}^{33}\end{array}$ & $\begin{array}{l}\text { Nonrandomized, } \\
\text { noncomparative } \\
\text { study (postmarketing } \\
\text { survey) }\end{array}$ & 272 & $\begin{array}{l}\text { Responder rates for at least } \\
28 \text { weeks (up to } 52 \text { weeks) } \\
\text { with ramosetron: } \\
50.00 \% \text { with } 2.5 \mu \text { g dose- } \\
\text { reduction group, } \\
35.71 \% \text { with } 5 \mu \mathrm{g} \text { dose- } \\
\text { maintenance group, } \\
22.50 \% \text { with } 10 \mu \mathrm{g} \text { dose } \\
\text { increase group. } \\
\text { The rate was further increased } \\
\text { subsequently. }\end{array}$ & $\begin{array}{l}\text { No statistical analysis was } \\
\text { reported. }\end{array}$ & $\begin{array}{l}\text { The lack of the delayed } \\
\text { increase in the incidence } \\
\text { of adverse events associated } \\
\text { with long-term treatment } \\
\text { was demonstrated. }\end{array}$ \\
\hline $\begin{array}{l}\text { Lee } \\
\text { et } \mathrm{al}^{32}\end{array}$ & $\begin{array}{l}\text { Multicenter, } \\
\text { randomized, } \\
\text { open-label design }\end{array}$ & 343 & $\begin{array}{l}\text { Responder rates during } 4 \text {-week } \\
\text { treatment: } \\
37 \% \text { with ramosetron, } \\
38 \% \text { with mebeverine. }\end{array}$ & $\begin{array}{l}\text { Responder rates for IBS } \\
\text { symptoms in the ramosetron } \\
\text { and mebeverine groups were } \\
\text { increased compared with } \\
\text { baselines }(P<0.00 \mathrm{I}) \text {. } \\
\text { There were no significant } \\
\text { differences in the responder } \\
\text { rates between the ramosetron } \\
\text { and mebeverine groups. }\end{array}$ & $\begin{array}{l}\text { Neither severe constipation } \\
\text { nor ischemic colitis was } \\
\text { reported by ramosetron- } \\
\text { treated patients. }\end{array}$ \\
\hline
\end{tabular}

Adverse events were reported by $7 \%$ of patients in the ramosetron-treatment group during the 4 -week treatment period. Constipation was the most commonly recorded adverse event in the ramosetron group (2\%). The major adverse event associated with these withdrawals in the ramosetron group was constipation. All of the adverse events were described as of mild or moderate severity. Absence of stool despite the use of rescue laxatives was defined as severe constipation. No serious adverse events, eg, severe constipation or ischemic colitis, were reported in the ramosetron and mebeverine groups. Laboratory values were not significantly changed by ramosetron treatment. Neither severe constipation nor ischemic colitis was reported by ramosetron-treated patients. ${ }^{32}$ Thus, for safety, ramosetron was well tolerated, as demonstrated by the lack of the increase in the incidence of adverse events associated with long-term treatment. ${ }^{33}$

5 - $\mathrm{HT}_{3}$-receptor antagonists improve symptoms in IBS$\mathrm{D}$, but have constipation as a side effect, with alosetron $>$ cilansetron $>$ ramosetron $>$ ondansetron. While both alosetron and cilansetron have been associated with ischemic colitis, this has not been reported with either ramosetron or ondansetron. The original doses recommended may well have been excessive, and careful dose titration starting with very low doses may well avoid severe side effects in the future. ${ }^{41}$

\section{Conclusion}

The long-term effectiveness of ramosetron in IBS has been useful in attaining relief of abdominal pain or discomfort, and improvements in abnormal bowel habits. Finally, ramosetron is associated with a low incidence of adverse events, such as abdominal distension, constipation, and hard stool, and ischemic colitis is unlikely to be caused by ramosetron. Thus, ramosetron would be the candidate of first choice for treating IBS-D clinically. Further studies to evaluate the long-term efficacy and safety of 
ramosetron are warranted in the form of randomized controlled trials.

\section{Disclosure}

The authors report no conflicts of interest in this work.

\section{References}

1. Longstreth GF, Thompson WG, Chey WD, Houghton LA, Mearin F, Spiller RC. Functional bowel disorders. Gastroenterology. 2006;130: 1480-1491.

2. Grundy D, Al-Chaer ED, Aziz Q, et al. Fundamentals of neurogastroenterology: basic science. Gastroenterology. 2006;130: 1391-1411.

3. Okano S, Ikeura Y, Inatomi N. Effects of tachykinin NK1 receptor antagonists on the viscerosensory response caused by colorectal distention in rabbits. J Pharmacol Exp Ther. 2002;300:925-931.

4. Gully D, Geslin M, Serva L, et al. 4-(2-Chloro-4-methoxy-5methylphenyl)-N-[(1S)-2-cyclopropyl-1-(3-fluoro-4-methylphenyl) ethyl]5-methyl-N-(2-propynyl)-1,3-thiazol-2-amine hydrochloride (SSR125543A): a potent and selective corticotrophin-releasing factor(1) receptor antagonist. I. Biochemical and pharmacological characterization. J Pharmacol Exp Ther. 2002;301:322-332.

5. Hirata T, Keto Y, Funatsu T, Akuzawa S, Sasamata M. Evaluation of the pharmacological profile of ramosetron, a novel therapeutic agent for irritable bowel syndrome. J Pharmacol Sci. 2007;104: 263-273.

6. Ito H, Hidaka K, Miyata K, Kamato T, Nishida A, Honda K. Characterization of YMO60, a potent and selective 5-hydroxytryptamine 3 receptor antagonist, in rabbit nodose ganglion and NIE-115 neuroblastoma cells. J Pharmacol Exp Ther. 1992;263:1127-1132.

7. Rabasseda X. Ramosetron, a 5-HT3 receptor antagonist for the control of nausea and vomiting. Drugs Today. 2002;38:75-89.

8. Miyata K, Kamato T, Yamano M, et al. Serotonin (5-HT)3 receptor blocking activities of YMO60, a novel 4, 5, 6, 7-tetrahydrobenzimidazole derivative, and its enantiomer in anesthetized rats. $J$ Pharmacol Exp Ther. 1991;259:815-819.

9. Färber L, Haus U, Späth M, Drechsler S. Physiology and pathophysiology of the 5-HT3 receptor. Scand J Rheumatol Suppl. 2004; 119:2-8.

10. Crowell MD. Role of serotonin in the pathophysiology of the irritable bowel syndrome. Br J Pharmacol. 2004;141:1285-1293.

11. Funatsu T, Takeuchi A, Hirata T, Keto Y, Akuzawa S, Sasamata M. Effect of ramosetron on conditioned emotional stress-induced colonic dysfunction as a model of irritable bowel syndrome in rats. Eur $J$ Pharmacol. 2007;573:190-195.

12. Hirata T, Funatsu T, Keto Y, Nakata M, Sasamata M. Pharmacological profile of ramosetron, a novel therapeutic agent for IBS. Inflammopharmacology. 2007;15:5-9.

13. Mayer EA, Berman S, Derbyshire SW, et al. The effect of the 5-HT3 receptor antagonist, alosetron, on brain responses to visceral stimulation in irritable bowel syndrome patients. Aliment Pharmacol Ther 2002;16:1357-1366.

14. Siriwardena AK, Budhoo MR, Smith EP, Kellum JM. A 5-HT3 receptor agonist induces neutrally mediated chloride transport in rat distal colon. J Surg Res. 1993;55:55-59.

15. Hansen MB. The enteric nervous system III: a target for pharmacological treatment. Pharmacol Toxicol. 2003;93:1-13.

16. Miyata K, Kamato T, Nishida A, et al. Role of the serotonin3 receptor in stress-induced defecation. J Pharmacol Exp Ther. 1992;261: 297-303.

17. Kozlowski CM, Green A, Grundy D, Boissonade FM, Bountra C. The 5-HT(3) receptor antagonist alosetron inhibits the colorectal distention induced depressor response and spinal c-fos expression in the anaesthetized rat. Gut. 2000;46:474-480.
18. Brandt LJ, Bjorkman D, Fennerty MB, et al. Systematic review on the management of irritable bowel syndrome in North America. Am J Gastroenterol. 2002;97:S7-S26.

19. Camilleri M, Northcutt AR, Kong S, Dukes GE, McSorley D, Mangel AW. Efficacy and safety of alosetron in women with irritable bowel syndrome: a randomised, placebo-controlled trial. Lancet. 2000;355:1035-1040.

20. Caras S, Krause G, Biesheuvel E, Steinborn C. Cilansetron shows efficacy in male and female non-constipated patients with irritable bowel syndrome in a United States study. Gastroenterology. 2001;120:A217.

21. Yamamoto C, Murakami H, Koyabu N, et al. Contribution of P-glycoprotein to efflux of ramosetron, a 5-HT3 receptor antagonist, across the bloodbrain barrier. J Pharm Pharmacol. 2002;54: 1055-1063.

22. Hirata T, Keto Y, Nakata M, et al. Effects of serotonin 5-HT3 receptor antagonists on stress-induced colonic hyperalgesia and diarrhoea in rats: a comparative study with opioid receptor agonists, a muscarinic receptor antagonist and a synthetic polymer. Neurogastroenterol Motil. 2008:20:557-565.

23. Matsueda K, Harasawa S, Hongo M, Hiwatashi N, Sasaki D. A randomized, double-blind, placebo-controlled clinical trial of the effectiveness of the novel serotonin type 3 receptor antagonist ramosetron in both male and female Japanese patients with diarrhea-predominant irritable bowel syndrome. Scand J Gastroenterol. 2008;43:1202-1211.

24. Ohta M, Suzuki T, Furuya T, et al. Novel 5-hydroxytryptamine (5-HT3) receptor antagonists. III. Pharmacological evaluations and molecular modeling studies of optically active 4,5,6,7-tetrahydro-1H-benzimidazole derivatives. Chem Pharm Bull (Tokyo). 1996;44: 1707-1716.

25. Akuzawa $\mathrm{S}$, lto $\mathrm{H}$, Yamaguchi T. Comparative study of $[3 \mathrm{H}]$ ramosetron and $[3 \mathrm{H}]$ granisetron binding in the cloned human 5-hydroxytryptamine 3 receptors. Jpn J Pharmacol. 1998;78:381-384.

26. Yamano M, Kamato T, Nishida A, et al. Serotonin (5-HT)3 receptor antagonism of 4,5,6,7-tetra-hydrobenzimidazole derivatives against 5-HT-induced bradycardia in anesthetized rats. Jpn J Pharmacol. 1994;65:241-248.

27. Spiller R. Serotoninergic modulating drugs for functional gastrointestinal diseases. Br J Clin Pharmacol. 2002;54:11-20.

28. Fanselow MS, Helmstetter FJ. Conditional analgesia, defensive freezing, and benzodiazepines. Behav Neurosci. 1988;102:233-243.

29. Kameyama T, Nagasaka M, Yamada K. Effects of antidepressant drugs on a quickly-learned conditioned-suppression response in mice. Neuropharmacology. 1985;24:285-290.

30. Matsueda K, Harasawa S, Hongo M, Hiwatashi N, Sasaki D. A phase II trial of the novel serotonin type 3 receptor antagonist ramosetron in Japanese male and female patients with diarrhea-predominant irritable bowel syndrome. Digestion. 2008;77:225-235.

31. Chang L, Ameen VZ, Dukes GE, McSorley DJ, Carter EG, Mayer EA. A dose-ranging, phase II study of the efficacy and safety of alosetron in men with diarrhea-predominant IBS. Am J Gastroenterol. 2005;100: $115-123$.

32. Lee KJ, Kim NY, Kwon JK, et al. Efficacy of ramosetron in the treatment of male patients with irritable bowel syndrome with diarrhea: a multicenter, randomized clinical trial, compared with mebeverine. Neurogastroenterol Motil. 2011;23:1098-1104.

33. Matsueda K, Arakawa T, Matsumoto T, Sasaki D. Long-term study of YM060 (ramosetron hydrochloride) in Japanese patients (male) with diarrhea-predominant irritable bowel syndrome. Rinsho Iyaku. 2008;24:655-678. Japanese with English abstract.

34. Naliboff BD, Berman S, Chang L, et al. Sex-related differences in IBS patients: central processing of visceral stimuli. Gastroenterology. 2003;124:1738-1747.

35. Berman S, Munakata J, Naliboff BD, et al. Gender differences in regional brain response to visceral pressure in IBS patients. Eur J Pain. 2000;4:157-172.

36. Yeo A, Boyd P, Lumsden S, et al. Association between a functional polymorphism in the serotonin transporter gene and diarrhoea predominant irritable bowel syndrome in women. Gut. 2004;53: $1452-1458$. 
37. Camilleri M. Is there a SERT-ain association with IBS? Gut. 2004;53: 1396-1399.

38. Camilleri M, Mayer EA, Drossman DA, et al. Improvement in pain and bowel function in female irritable bowel patients with alosetron, a 5-HT3 receptor antagonist. Aliment Pharmacol Ther. 1999;13:1149-1159.

39. Andresen V, Montori VM, Keller J, West CP, Layer P, Camilleri M. Effects of 5-hydroxytryptamine (serotonin) type 3 antagonists on symptom relief and constipation in nonconstipated irritable bowel syndrome: a systematic review and meta-analysis of randomized controlled trials. Clin Gastroenterol Hepatol. 2008;6:545-555.
40. Suh DC, Kahler KH, Choi IS, Shin H, Kralstein J, Shetzline M. Patients with irritable bowel syndrome or constipation have an increased risk for ischaemic colitis. Aliment Pharmacol Ther. 2007;25:681-692.

41. Spiller RC. Targeting the 5-HT3 receptor in the treatment of irritable bowel syndrome. Curr Opin Pharmacol. 2011;11:68-74.

\section{Publish your work in this journal}

Clinical and Experimental Gastroenterology is an international, peerreviewed, open access journal, publishing all aspects of gastroenterology in the clinic and laboratory, including: Pathology, pathophysiology of gastrointestinal disease; Investigation and treatment of gastointestinal disease; Pharmacology of drugs used in the alimentary tract;
Immunology/genetics/genomics related to gastrointestinal disease. This journal is indexed on CAS. The manuscript management system is completely online and includes a very quick and fair peer-review system. Visit http://www.dovepress.com/testimonials.php to read real quotes from published authors.

Submit your manuscript here: http://www.dovepress.com/clinical-and-experimental-gastroenterology-journal 